\title{
Economic Growth in the Euro Zone Countries and Other Member States of the European Union in the Years 2006 - 2017 - Comparative Analysis
}

\author{
Krzysztof Dobrowolski ${ }^{1, *}$, and Grzegorz Pawłowski ${ }^{1}$ \\ ${ }^{1}$ University of Gdańsk, Faculty of Economics, 119/121 Armii Krajowej St., 81-824 Sopot, Poland
}

\begin{abstract}
The aim of the conducted research is to verify III hypotheses. Hypothesis I: changes in GDP and its components should demonstrate higher dynamics in the euro zone countries than in countries using national currencies, taking into account differences in their level of economic development. Hypothesis II: in countries that joined the euro zone during the period under examination, the analyzed indicators should demonstrate higher dynamics after the adoption of the common currency. Hypothesis III: the index of final consumption expenditure of general government should demonstrate lower dynamics in the euro zone countries and a decline in dynamics after the adoption of the euro in the countries that have done so during the period considered. Statistical material was analyzed. Data on GDP dynamics, investments, final consumption expenditure of households and non-profit institutions serving households (later referred to as: "final consumption expenditure"), final consumption expenditure of general government, export and import were used.

The research methods used were: the method of analysis and logical construction and a statistical one. The hypotheses tested were only partially confirmed.
\end{abstract}

\section{Introduction}

The aim of the conducted research is to compare the dynamics of selected economic indicators in the European Union member states and beyond and to formulate conclusions on the impact of the euro on the possibilities of economic development, in the context of emerging statements that the use of the common currency is a negative factor affecting economic growth.

The following hypotheses were formulated:

- Hypothesis I: changes in GDP and its components should demonstrate higher dynamics in the euro zone countries than in countries using national currencies, taking into account differences in their level of economic development.

- Hypothesis II: in countries that joined the euro zone during the period under examination, the analyzed indicators should demonstrate higher dynamics after the adoption of the common currency.

\footnotetext{
* Corresponding author: k.dobrowolski@ug.gda.pl
} 
- Hypothesis III: due to stricter requirements in relation to the euro zone countries in terms of maintaining budgetary discipline, the index of final consumption expenditure of general government should demonstrate lower dynamics in these countries and a decline in dynamics after the adoption of the euro in the countries that have done so during the period considered.

\section{Methodology}

The years 2006 - 2017, i.e. the period before the crisis on the financial markets, the crisis years and the post-crisis period, were adopted for the research period. The following indicators were analyzed: GDP, final consumption expenditure of general government, final consumption expenditure, investments, export and import.

The countries analysed were divided into four groups. Group I included: Greece, Ireland, Spain, Italy and Portugal, the countries most affected by the crisis on the financial markets. They are often referred to as the PIIGS acronym. It was decided to distinguish these economies so that the economic problems experienced by them would not falsify the results of the analysis. According to the authors, the problems of these countries did not result from belonging to the euro zone, but from mistakes made in the economic policy, although in individual countries these mistakes were of different origin.

The second group includes: Belgium, Germany, France, Luxembourg, the Netherlands, Austria and Finland, that is countries with stabilized economies that joined the euro zone at the time of its creation.

The third group consists of: Denmark, Sweden and the United Kingdom, countries belonging to the European Union from the beginning with stabilized economies in which national currencies operate.

Group IV consists of: the Czech Republic, Hungary, Poland, Romania and Bulgaria, which are the countries of economic transformation, later members of the European Union in which national currencies are still in force. Romania and Bulgaria joined the European Union on January 1, 2007, that is during the adopted research period, but because they still have national currencies, this fact does not affect the obtained results.

Countries outside the euro zone have been divided into two groups due to the specific character of their economies, which affects the dynamics of economic growth. In the IV group countries that underwent a period of economic transformation from a planned economy system into a market economy system, a lower starting base and the possibility of using simple development reserves influenced the growth dynamics of the analyzed indicators. In countries with a stable economy, these factors do not exist and hence the dynamics of economic growth is naturally at a lower level. Grouping together all countries using national currencies and comparing them with the countries of group II (euro zone, stabilized economies) could lead to wrong conclusions.

For each year of the analyzed period average dynamics indexes were calculated on the basis of Eurostat or OECD data for each analyzed group: GDP, non-investment government expenditure, final consumption expenditure, investment expenditure, export and import, which were then analyzed.

For the remaining European Union countries, which adopted the euro during the period under examination, the analysis of individual indicators was made before and after resignation from national currencies. 


\section{Changes in GDP dynamics}

Table 1. Average dynamics of gross domestic product in particular groups of countries in $2006-2017(\%)$.

\begin{tabular}{|c|c|c|c|c|c|c|c|c|c|c|c|c|}
\hline Countries/year & $\mathbf{2 0 0 6}$ & $\mathbf{2 0 0 7}$ & $\mathbf{2 0 0 8}$ & $\mathbf{2 0 0 9}$ & $\mathbf{2 0 1 0}$ & $\mathbf{2 0 1 1}$ & $\mathbf{2 0 1 2}$ & $\mathbf{2 0 1 3}$ & $\mathbf{2 0 1 4}$ & $\mathbf{2 0 1 5}$ & $\mathbf{2 0 1 6}$ & $\mathbf{2 0 1 7}$ \\
\hline Group I & 3,8 & 3,3 & $-0,8$ & $-4,2$ & 0,0 & $-1,7$ & $-3,4$ & $-1,2$ & 2,3 & 6,3 & 2,1 & 3,3 \\
\hline Group II & 3,6 & 4,3 & 0,7 & $-4,4$ & 2,8 & 2,5 & $-0,2$ & 0,6 & 1,7 & 1,5 & 1,9 & 2,5 \\
\hline Group III & 3,7 & 2,2 & $-0,5$ & $-4,8$ & 3,2 & 1,8 & 0,5 & 1,4 & 2,4 & 2,8 & 2,4 & 2,1 \\
\hline Group IV & 6,4 & 5,4 & 4,4 & $-3,6$ & 1,0 & 2,5 & 0,1 & 1,5 & 2,9 & 4,0 & 3,3 & 4,7 \\
\hline
\end{tabular}

Source: the authors' own calculations based on [1]

In 2006, the average GDP dynamics was slightly higher (by 0.1 percentage point) in the third group (countries with a stable economy with national currencies) than in the second group ( euro zone countries with a stable economy). In the years $2007-2009$, the situation has changed. In 2007, Group II recorded higher average GDP dynamics (by 2.1 percentage points) than Group III. In 2008, Group II recorded an increase in the average GDP growth and Group III a decline. In 2009 in both groups there was a decrease in the average GDP growth rate, but in the second group it was lower (by 0.4 percentage point) than in the third group. In this period (2006-2009), it can be assumed that the hypothesis I was confirmed.

In the period 2010 - 2017, i.e. in the period of slow recovery from the financial markets crisis and stabilization of the situation, only in 2011 and 2017 the average GDP growth was higher in Group II, in the remaining years Group III countries were characterized by higher average GDP dynamics. These differences can, at least partially, be attributed to more flexible mechanisms for restoring the economy to a path of growth when using national currencies. In this case, the hypothesis I has not been sufficiently proven.

The situation in Group I (PIIGS countries, the euro area) is interesting. In 2006-2007 they were characterized by higher average GDP dynamics (by 0.1 percentage point in 2006 and by 1.1 percentage points in 2007) than the countries of Group III, which would confirm the hypothesis I. In the following years, however, the effects of the crisis were painfully felt, which was reflected in the decline in the average GDP growth in the period 2008 - 2013, except for 2010 (average GDP growth at $0 \%$ ). The changes in the economic policy have brought effects and in 2014-2017, the growth of the average dynamics of GDP in this group of countries was noted. In 2014, the increase in the average GDP growth was slightly lower in Group I (by 0.1 percentage point) than in Group III, in 2015 higher (by 3.5 percentage points), in the following year lower (by 3 percentage points) and in 2017 higher (by 1.2 percentage points) than in Group III. Undoubtedly, the average GDP growth rate in this group of countries was affected by the lower level of the base, shaped by the decline in the average GDP growth in previous years and the launch of development reserves thanks to implemented reforms. Nevertheless, the euro was not a factor preventing the PIIGS economy from returning to the path of growth, which positively verifies the hypothesis I.

Practically throughout the analyzed period, the highest average GDP growth (in 2009 the lowest decrease) was recorded by the countries of Group IV, that is developing countries. The exceptions were the years: 2010, in which the higher average GDP dynamics was recorded in Groups II and III, 2011 (the same as in Group II), 2012, where the average GDP growth was higher in the Group III and 2015, in which the average GDP dynamics was higher in Group I. Comparing the situation in Group IV and Group I after 2013, it can be concluded that regardless of whether the country maintains the national currency (Group IV), or whether it is located in the euro zone (Group I), the low base and the launch of development reserves result in relatively high GDP dynamics. 
Table 2. The dynamics of gross domestic product in individual countries in the years $2006-2017(\%)$.

\begin{tabular}{|c|c|c|c|c|c|c|c|c|c|c|c|c|}
\hline Country/Year & $\mathbf{2 0 0 6}$ & $\mathbf{2 0 0 7}$ & $\mathbf{2 0 0 8}$ & $\mathbf{2 0 0 9}$ & $\mathbf{2 0 1 0}$ & $\mathbf{2 0 1 1}$ & $\mathbf{2 0 1 2}$ & $\mathbf{2 0 1 3}$ & $\mathbf{2 0 1 4}$ & $\mathbf{2 0 1 5}$ & $\mathbf{2 0 1 6}$ & $\mathbf{2 0 1 7}$ \\
\hline Slovenia & 5,7 & 6,9 & 3,3 & $-7,8$ & 1,2 & 0,6 & $-2,7$ & $-1,1$ & 3,0 & 2,3 & 3,1 & 5,0 \\
\hline Cyprus & 4,5 & 4,8 & 3,9 & $-1,8$ & 1,3 & 0,3 & $-3,1$ & $-5,9$ & $-1,4$ & 2,0 & 3,4 & 3,9 \\
\hline Malta & 1,8 & 4,0 & 3,3 & $-2,5$ & 3,5 & 1,3 & 2,7 & 4,6 & 8,1 & 9,6 & 5,2 & 6,4 \\
\hline Slovakia & 8,5 & 10,8 & 5,6 & $-5,4$ & 5,0 & 2,8 & 1,7 & 1,5 & 2,8 & 3,9 & 3,3 & 3,4 \\
\hline Estonia & 10,3 & 7,7 & $-5,4$ & $-14,7$ & 2,3 & 7,6 & 4,3 & 1,9 & 2,9 & 1,7 & 2,1 & 4,9 \\
\hline Latvia & 11,9 & 10,0 & $-3,5$ & $-14,4$ & $-3,9$ & 6,4 & 4,0 & 2,4 & 1,9 & 3,0 & 2,2 & 4,5 \\
\hline Lithuania & 7,4 & 11,1 & 2,6 & $-14,8$ & 1,6 & 6,0 & 3,8 & 3,5 & 3,5 & 2,0 & 2,3 & 3,8 \\
\hline
\end{tabular}

Source: Eurostat, https:/ec.europa.eu/eurostat/web/national-accounts/data/main-tables

The countries presented in Table 2 have a different length of the euro zone membership. The longest one is that of Slovenia, which introduced the euro on 1 January 2007, the shortest Lithuania, which was admitted to the euro zone on January 1, 2015. In the case of Slovenia, it remained only one year of the examined period outside the euro zone, while Lithuania was in the euro zone only for three years of the examined period. This causes difficulties in the inference process compounded by the years of crisis in the financial markets.

Based on the data in Table 2, one can formulate a general conclusion that in the examined countries there was no permanent increase in GDP growth after the adoption of the euro (excluding the crisis period in the financial markets). This applies to countries that joined the euro zone in the year of the first symptoms of the crisis in the financial markets (Slovenia) as well as countries that adopted the euro during the crisis (Cyprus, Slovakia) and countries that joined the euro zone in the period of overcoming the effects of the crisis (Estonia, Latvia, Lithuania).

On the other hand, Malta's situation is interesting, especially against the background of Cyprus. Both countries introduced the euro on January 1, 2008. In both countries the year of adoption of the euro was characterized by similar dynamics of GDP $(3.9 \%$ in the case of Cyprus, 3.3\% in the case of Malta), whereas in previous years the GDP growth in Cyprus was higher than in 2008, and in Malta it was higher only in 2007. In both countries 2009 was characterized by a decline in GDP, more significant in Malta, whereas in Cyprus such a situation occurred in 2012-2014. In Malta, from 2013, GDP growth rates have grown, and in some years more considerably than before the adoption of the euro. In this country, therefore, with the exception of the crisis years, the hypothesis II was confirmed.

It is also worth noting that in 2017 in all the examined countries, GDP growth was higher than in the previous year. This may denote that after the crisis and the years of overcoming its effects, the countries of the euro zone are returning to the path of growth, although it is difficult to expect GDP growth in the range of $11.9-7.4 \%$, as observed in some of them before the crisis and adoption of the euro.

\section{Changes in the dynamics of final consumption expenditure of general government}

For the most part of the analyzed period, the average growth rate of non-investment expenditure of the public sector was higher in the euro zone countries with a stable economy (Group II) than in countries with a stable economy using national currencies (Group II). The exceptions are the years 2010, 2012, 2014 and 2015, in which the situation was different. In 
general, however, the hypothesis III has not been confirmed in relation to these groups of countries.

Table 3. Average dynamics of final consumption expenditure of general government in particular groups of countries in $2006-2017(\%)$.

\begin{tabular}{|c|c|c|c|c|c|c|c|c|c|c|c|c|}
\hline Countries/Year & $\mathbf{2 0 0 6}$ & $\mathbf{2 0 0 7}$ & $\mathbf{2 0 0 8}$ & $\mathbf{2 0 0 9}$ & $\mathbf{2 0 1 0}$ & $\mathbf{2 0 1 1}$ & $\mathbf{2 0 1 2}$ & $\mathbf{2 0 1 3}$ & $\mathbf{2 0 1 4}$ & $\mathbf{2 0 1 5}$ & $\mathbf{2 0 1 6}$ & $\mathbf{2 0 1 7}$ \\
\hline Group I & 3,0 & 3,6 & 1,1 & 1,1 & $-1,8$ & $-2,9$ & $-3,6$ & $-2,4$ & 0,2 & 1,2 & 1,1 & 0,4 \\
\hline Group II & 2,7 & 2,1 & 2,5 & 2,7 & 0,8 & 0,5 & 1,0 & 1,3 & 0,9 & 1,2 & 1,8 & 1,3 \\
\hline Group III & 2,0 & 0,9 & 2,2 & 2,1 & 1,1 & 0,1 & 1,1 & 0,5 & 2,0 & 1,4 & 1,4 & 0,6 \\
\hline Group IV & 1,6 & $-0,8$ & 3,5 & 1,0 & 0,1 & $-0,5$ & $-1,1$ & 1,0 & 2,2 & 1,4 & 2,0 & 1,8 \\
\hline
\end{tabular}

Source: the authors' own calculation based on [1]

For the most part of the analyzed period, the average growth rate of non-investment expenditure of the public sector was higher in the euro zone countries with a stable economy (Group II) than in countries with a stable economy using national currencies (Group II). The exceptions are the years 2010, 2012, 2014 and 2015, in which the situation was different. In general, however, the hypothesis III has not been confirmed in relation to these groups of countries.

In developing countries, not belonging to the euro zone (Group IV), the average dynamics of the examined indicator was lower than in the second group in the periods 2006-2007 and 2009-2013, while in the years 2008 and 2014 - 2017 the average dynamics in the discussed group of countries was higher than in Group II. Therefore, the hypothesis III for the period 2006 - 2013 has not been confirmed, however since 2014 the change in the trend has been consistent with the hypothesis III.

In the countries of Group I (PIIGS) in the years 2006 - 2007, the average dynamics of non-investment expenditure in the public sector was higher than in all other groups of countries, which was undoubtedly one of the reasons for the serious crisis (except Ireland). Since 2008, this trend has changed, only in 2009 the average dynamics of the indicator was slightly higher (by 0.1 percentage point) in Group I than in Group IV, and in 2015 at the level of Group II index. In this case, however, it is difficult to find confirmation of hypothesis III, because the limitations of public spending resulted from the implemented repair programs.

Table 4. The dynamics of final consumption expenditure of general government in individual countries in $2006-2017$ (\%).

\begin{tabular}{|c|c|c|c|c|c|c|c|c|c|c|c|c|}
\hline Countries/Year & $\mathbf{2 0 0 6}$ & $\mathbf{2 0 0 7}$ & $\mathbf{2 0 0 8}$ & $\mathbf{2 0 0 9}$ & $\mathbf{2 0 1 0}$ & $\mathbf{2 0 1 1}$ & $\mathbf{2 0 1 2}$ & $\mathbf{2 0 1 3}$ & $\mathbf{2 0 1 4}$ & $\mathbf{2 0 1 5}$ & $\mathbf{2 0 1 6}$ & $\mathbf{2 0 1 7}$ \\
\hline Slovenia & 3,1 & 1,9 & 4,9 & 2,4 & $-0,5$ & $-0,7$ & $-2,2$ & $-2,1$ & $-1,2$ & 2,7 & 2,5 & 2,3 \\
\hline Cyprus & 7,2 & 3,4 & 6,4 & 6,3 & $-0,3$ & 2,1 & $-1,8$ & $-8,1$ & $-7,2$ & $-2,6$ & $-0,4$ & 2,7 \\
\hline Malta & 4,9 & 0,9 & 12,3 & $-3,3$ & 1,6 & 3,4 & 5,7 & $-0,4$ & 6,6 & 3,7 & $-2,7$ & $-0,9$ \\
\hline Slovakia & 9,2 & 0,3 & 6,5 & 6,2 & 1,7 & $-1,8$ & $-2,1$ & 2,2 & 5,2 & 5,4 & 1,6 & 0,2 \\
\hline Estonia & 5,5 & 6,6 & 4,6 & $-3,2$ & $-0,4$ & 1,3 & 3,2 & 2,7 & 2,6 & 3,3 & 1,9 & 0,8 \\
\hline Latvia & 6,1 & 3,3 & 2,4 & $-10,7$ & $-8,1$ & 3,0 & 0,3 & 1,6 & 1,9 & 1,9 & 2,7 & 4,1 \\
\hline Lithuania & 2,1 & 1,9 & 0,2 & $-1,3$ & $-3,2$ & $-0,4$ & 1,3 & 0,7 & 0,3 & 0,2 & 1,3 & 1,2 \\
\hline
\end{tabular}

Source: [1]

The hypothesis III has been confirmed for some countries. In Slovenia, after the adoption of the euro in 2007 , non-investment public expenditure was significantly reduced - 
the dynamics was negative for the majority of the analyzed period, a similar situation occurred in Cyprus.

In Estonia, hypothesis III is confirmed if we assume that the drop in non-investment public expenditure in 2009-2010 was caused by the effects of the crisis on the financial markets. In the years 2006 - 2008, a high growth rate of the expenditure was recorded, within the limits of $4.6-6.6 \%$, while after the adoption of the euro this dynamics decreased significantly, to the level of $0.8-3.3 \%$. In the case of Latvia, the growth dynamics of non-investment public expenditure after the adoption of the euro can also be seen, but in 2017 this indicator increased to $4.1 \%$, higher than in the years preceding the accession to the euro zone, except for 2006 (6.1\%). In Lithuania, after the adoption of the euro in 2015, the dynamics of the examined indicator increased in relation to the previous period. In the remaining countries (Malta, Slovakia) the indicator changed irregularly, there were periods of absolute expenditure decrease, decrease in its growth rate and periods of dynamics growth.

\section{Changes in the dynamics of gross investments}

Table 5. Average gross investment dynamics in particular groups of countries in 2006 - 2017 (\%).

\begin{tabular}{|c|c|c|c|c|c|c|c|c|c|c|c|c|}
\hline Countries/Year & $\mathbf{2 0 0 6}$ & $\mathbf{2 0 0 7}$ & $\mathbf{2 0 0 8}$ & $\mathbf{2 0 0 9}$ & $\mathbf{2 0 1 0}$ & $\mathbf{2 0 1 1}$ & $\mathbf{2 0 1 2}$ & $\mathbf{2 0 1 3}$ & $\mathbf{2 0 1 4}$ & $\mathbf{2 0 1 5}$ & $\mathbf{2 0 1 6}$ & $\mathbf{2 0 1 7}$ \\
\hline Group I & 7,3 & 5,0 & $-5,1$ & $-13,0$ & $-8,1$ & $-8,3$ & $-8,3$ & $-5,5$ & 3,6 & 8,5 & 14,1 & 1,1 \\
\hline Group II & 3,7 & 7,1 & 3,2 & $-9,6$ & 0,3 & 6,2 & $-0,2$ & $-1,4$ & 1,8 & 1,4 & 3,8 & 3,9 \\
\hline Group III & 8,6 & 4,7 & $-2,3$ & $-13,4$ & 1,6 & 2,8 & 1,9 & 2,2 & 5,2 & 4,3 & 4,5 & 4,5 \\
\hline Group IV & 11,1 & 20,1 & 10,4 & $-14,9$ & $-5,1$ & 2,0 & $-0,5$ & 0,2 & 6,6 & 5,7 & $-5,9$ & 6,8 \\
\hline
\end{tabular}

Source: [1]

The average investment dynamics in Group II (euro zone countries with a stable economy) does not confirm the hypothesis I. Apart from the years 2007 - 2009 and 2011, the average investment dynamics was favourable in Group III (euro zone countries with national currencies). Investments in the economically developed countries of the euro zone demonstrated greater resilience to the crisis situation (2008-2009) than in the third group, but during the period of stabilization, investments not only increased slowly, but also a two-year decline in their level was recorded.

In Group I (PIIGS), the decline in investments was the longest (2008 - 2013), followed by a period of steady growth in investments in 2014-2016, which ended in 2017 with a significant decline in the dynamics of the indicator. Considering the long period of decline in the investment level and the short period of their growth, it should be assumed that the hypothesis I was not confirmed.

In developing countries with national currencies there were alternating years of high average investment dynamics, drop in their level and low average dynamics. In the years $2006-2008$, the average growth rate of investments in Group I was much higher than in the euro zone countries, after which in 2009 there was a steep decline in the average level of investment, even deeper than in the PIIGS countries. It continued, although not at such a level, in 2010, 2012 and 2016. In 2014 and 2017, the average investment dynamics in Group IV was higher than in other groups of countries. In the average investment dynamics in Group IV there is no clear trend confirming the hypothesis I. A significant factor affecting the level of investments is the presence of EU funds, which in particular years are used differently in these countries. 
Table 6. Gross investment dynamics in individual countries in $2006-2017$ (\%).

\begin{tabular}{|c|c|c|c|c|c|c|c|c|c|c|c|c|}
\hline Countries/Year & $\mathbf{2 0 0 6}$ & $\mathbf{2 0 0 7}$ & $\mathbf{2 0 0 8}$ & $\mathbf{2 0 0 9}$ & $\mathbf{2 0 1 0}$ & $\mathbf{2 0 1 1}$ & $\mathbf{2 0 1 2}$ & $\mathbf{2 0 1 3}$ & $\mathbf{2 0 1 4}$ & $\mathbf{2 0 1 5}$ & $\mathbf{2 0 1 6}$ & $\mathbf{2 0 1 7}$ \\
\hline Slovenia & 10,2 & 12,0 & 7,0 & $-22,0$ & $-13,3$ & $-4,9$ & $-8,8$ & 3,2 & 1,1 & $-1,6$ & $-3,6$ & 10,3 \\
\hline Cyprus & 21,0 & 7,8 & 8,8 & $-13,6$ & $-2,6$ & $-12,1$ & $-20,5$ & $-12,9$ & $-17,5$ & 13,6 & 35,0 & 27,8 \\
\hline Malta & 2,6 & 5,6 & $-9,2$ & $-11,8$ & 26,4 & $-16,1$ & 1,5 & 1,3 & 6,8 & 56,8 & 1,7 & $-7,6$ \\
\hline Slovakia & 9,1 & 8,9 & 1,6 & $-18,7$ & 7,2 & 12,7 & $-9,0$ & $-0,9$ & 3,0 & 19,8 & $-8,3$ & 3,2 \\
\hline Estonia & 22,9 & 10,3 & $-13,1$ & $-36,7$ & $-2,7$ & 34,4 & 12,7 & 1,5 & $-8,7$ & $-2,9$ & $-1,2$ & 13,1 \\
\hline Latvia & 15,1 & 22,5 & $-9,1$ & $-33,3$ & $-19,8$ & 24,0 & 14,4 & $-6,0$ & 0,1 & $-0,5$ & $-15,0$ & 16,0 \\
\hline Lithuania & 19,6 & 22,3 & $-4,0$ & $-38,9$ & 1,5 & 20,1 & $-1,8$ & 8,3 & 5,8 & 4,8 & $-0,5$ & 7,3 \\
\hline
\end{tabular}

Source: Eurostat, https://ec.europa.eu/eurostat/web/national-accounts/data/main-tables

The lack of a clear trend in the dynamics of investment in particular countries (Table 5) does not allow confirmation of hypothesis II. In no examined country, the dynamics of investments after the adoption of the euro was permanently higher than before this event, without taking into account the decreases caused by the financial crisis. In the case of Cyprus, after the adoption of the euro, there was a six-year period of decline in the level of investment, in other countries decline occurred irregularly in certain years. The failure to confirm the hypothesis II in the case of investments is significant in that the adoption of the euro eliminates the exchange rate risk and should support their development within the common currency zone.

\section{Changes in the dynamics of consumption expenditure}

Table 7. Average dynamics of consumption expenditure in particular groups of countries in $2006-2017$ (\%).

\begin{tabular}{|c|c|c|c|c|c|c|c|c|c|c|c|c|}
\hline Countries/Year & $\mathbf{2 0 0 6}$ & $\mathbf{2 0 0 7}$ & $\mathbf{2 0 0 8}$ & $\mathbf{2 0 0 9}$ & $\mathbf{2 0 1 0}$ & $\mathbf{2 0 1 1}$ & $\mathbf{2 0 1 2}$ & $\mathbf{2 0 1 3}$ & $\mathbf{2 0 1 4}$ & $\mathbf{2 0 1 5}$ & $\mathbf{2 0 1 6}$ & $\mathbf{2 0 1 7}$ \\
\hline Group I & 3,2 & 3,6 & 0,9 & $-1,8$ & $-0,8$ & $-3,3$ & $-4,2$ & $-2,0$ & 1,1 & 2,0 & 1,8 & 1,3 \\
\hline Group II & 2,2 & 2,0 & 1,5 & 0,7 & 1,3 & 1,0 & 0,7 & 0,6 & 0,9 & 1,5 & 1,8 & 2,1 \\
\hline Group III & 2,3 & 2,1 & 0,7 & $-0,8$ & 1,6 & 0,3 & 1,0 & 1,1 & 1,8 & 2,1 & 2,1 & 1,4 \\
\hline Group IV & 5,3 & 5,6 & 3,8 & $-2,2$ & $-0,1$ & 0,9 & 0,2 & 0,2 & 2,8 & 3,5 & 4,0 & 4,8 \\
\hline
\end{tabular}

Source: [1]

In the years 2006 - 2007, the average dynamics of consumption expenditure was at a similar level in Group II (countries of the euro zone with a stable economy) and Group III (countries with a stable economy with national currencies). Group II proved more resilient to the crisis years (2008 - 2009), but countries with national currencies re-built and increased consumption more quickly in the period 2010 - 2016 (except in 2012, in which the average growth rate in consumption expenditure was 0.3 percentage point higher in Group II). It was not until 2017 that the average consumption growth was higher in Group II (by 0.7 percentage point).

In Group I (PIIGS), the average dynamics of consumption expenditure in 2006-2007 was higher than in the countries of Groups II and III, which unfortunately ended with a decreasing level of consumption in 2009 - 2013, which was affected by the implemented repair programs. Consumption expenditure has been increasing since 2014, but since 2016 the average growth rate has been slowing down. 
In Group IV (developing countries with national currencies), in 2006-2008, the average dynamics of consumption expenditure was the highest among all groups. In 2009-2010 the level of the expenditure decreased, but since 2014 there has been a systematic increase in the average dynamics, higher not only than growth in the euro zone, but also in the third group.

In general, changes in the average dynamics of consumption expenditure do not confirm the hypothesis I.

Table 8. Dynamics of consumption expenditure in individual countries in $2006-2017$ (\%).

\begin{tabular}{|c|c|c|c|c|c|c|c|c|c|c|c|c|}
\hline Countries/Year & $\mathbf{2 0 0 6}$ & $\mathbf{2 0 0 7}$ & $\mathbf{2 0 0 8}$ & $\mathbf{2 0 0 9}$ & $\mathbf{2 0 1 0}$ & $\mathbf{2 0 1 1}$ & $\mathbf{2 0 1 2}$ & $\mathbf{2 0 1 3}$ & $\mathbf{2 0 1 4}$ & $\mathbf{2 0 1 5}$ & $\mathbf{2 0 1 6}$ & $\mathbf{2 0 1 7}$ \\
\hline Slovenia & 1,7 & 5,2 & 3,0 & 1,3 & 0,8 & $-0,2$ & $-2,4$ & $-3,6$ & 1,1 & 2,3 & 3,8 & 3,0 \\
\hline Cyprus & 5,0 & 8,7 & 7,6 & $-3,8$ & 2,5 & $-0,1$ & $-1,4$ & $-6,4$ & $-1,0$ & 1,6 & 2,6 & 3,9 \\
\hline Malta & 3,3 & 0,7 & 2,7 & 0,5 & 0,2 & 3,0 & 1,1 & 1,4 & 3,4 & 4,7 & 1,3 & 2,6 \\
\hline Slovakia & 6,8 & 5,7 & 6,2 & 1,1 & 0,7 & $-0,9$ & $-0,8$ & $-0,1$ & 2,3 & 3,0 & 2,4 & 2,7 \\
\hline Estonia & 11,0 & 8,4 & $-2,7$ & $-12,2$ & $-1,2$ & 3,0 & 4,0 & 3,3 & 3,2 & 4,2 & 3,7 & 1,8 \\
\hline Latvia & 16,4 & 8,8 & $-5,5$ & $-14,7$ & 0,2 & 3,0 & 2,5 & 4,3 & 1,5 & 2,4 & 3,2 & 4,8 \\
\hline Lithuania & 7,5 & 10,0 & 3,1 & $-13,8$ & $-3,3$ & 3,4 & 2,7 & 3,5 & 3,2 & 3,2 & 4,2 & 3,3 \\
\hline
\end{tabular}

Source: [1]

In Slovenia, after the adoption of the euro, there was a period of decline in the growth of consumption expenditure, which subsequently transformed into the one of an absolute drop in the level of the expenditure. It was not until 2014 that the period of growth in consumption expenditure dynamics started, however in 2017 it decreased. In the case of Cyprus, the dynamics of consumption expenditure has permanently assumed positive values only from 2015. In the Slovak economy, after the period of declining consumption expenditure in 20112013, its dynamics also took positive values. In the case of Malta, Lithuania and Estonia there was no drop in consumption expenditure after the adoption of the euro, their dynamics demonstrated positive values. The upward trend in consumption dynamics after the adoption of the euro occurred in the Latvian economy. In the analyzed countries, the dynamics of consumption expenditure was not permanently higher than before the adoption of the euro (excluding the crisis period in the financial markets). Generally, the hypothesis II did not find any confirmation.

\section{Changes in export dynamics}

Table 9. Average export dynamics in particular groups of countries in $2006-2017$ (\%).

\begin{tabular}{|c|c|c|c|c|c|c|c|c|c|c|c|c|}
\hline Countries/Year & $\mathbf{2 0 0 6}$ & $\mathbf{2 0 0 7}$ & $\mathbf{2 0 0 8}$ & $\mathbf{2 0 0 9}$ & $\mathbf{2 0 1 0}$ & $\mathbf{2 0 1 1}$ & $\mathbf{2 0 1 2}$ & $\mathbf{2 0 1 3}$ & $\mathbf{2 0 1 4}$ & $\mathbf{2 0 1 5}$ & $\mathbf{2 0 1 6}$ & $\mathbf{2 0 1 7}$ \\
\hline Group I & 7,4 & 8,3 & $-0,9$ & $-10,6$ & 8,3 & 4,6 & 1,9 & 3,3 & 6,7 & 11,2 & 2,9 & 6,4 \\
\hline Group II & 8,7 & 6,9 & 2,9 & $-12,9$ & 10,6 & 5,5 & 2,1 & 2,0 & 4,5 & 4,3 & 3,5 & 5,1 \\
\hline Group III & 10,5 & 2,2 & 2,2 & $-10,8$ & 6,9 & 6,5 & 0,8 & 0,5 & 3,7 & 4,3 & 2,8 & 4,5 \\
\hline Group IV & 13,5 & 12,9 & 3,8 & $-8,7$ & 13,0 & 9,6 & 2,0 & 8,0 & 7,1 & 6,5 & 6,7 & 7,1 \\
\hline
\end{tabular}

Source: the authors' own calculations based on [2]

The average export dynamics for the majority of the analyzed period was higher in the second group (countries of the euro zone with a stabilized economy) than in the third group (countries with a stable economy with national currencies). The exceptions are the years: 2006 and 2011, in which the average export dynamics was higher (respectively 1.8 percentage 
points and 1 percentage point) in Group III. In 2009 a deeper decline in export (by 2.1 percentage points) in Group II was observed, while in 2015 the average growth rate of export was in both groups the same.

Also in Group I (PIIGS countries) for the majority of the analyzed period, the average export dynamics was higher than in Group III. The exceptions are the years 2006 and 2011 (the same as in the case of Group II), in which the average export dynamics was higher in the third group by 3.1 percentage points and 1.9 percentage points respectively. In 2008, there was a drop in export in Group I, with the growth dynamics in Group III, while in 2009, the fall in export in Group I was lower by 0.2 percentage point than in Group III.

The average export dynamics in the analyzed period was the highest in Group IV among all groups of countries except 2012 (higher average dynamics of export in Group II by 0.1 percentage point) and 2015 (higher average dynamics of export in Group I by 4.7 percentage points). In 2009, Group IV recorded the lowest drop in export of all groups. The high dynamics of export in Group IV can be partially attributed to a low base and the use of development reserves. The average export dynamics for the entire analyzed period was $4.1 \%$ for Group I, 3.6\% for Group II, 2.8\% for Group III and 6.8\% for Group IV.

Generally, it can be concluded that the hypothesis I has been confirmed. The higher dynamics of export in the euro zone results to a large extent from the elimination of exchange rate risk and reduced transaction costs in this zone.

Table 10. Export dynamics in individual countries in $2006-2017$ (\%).

\begin{tabular}{|c|c|c|c|c|c|c|c|c|c|c|c|c|}
\hline Countries/Year & $\mathbf{2 0 0 6}$ & $\mathbf{2 0 0 7}$ & $\mathbf{2 0 0 8}$ & $\mathbf{2 0 0 9}$ & $\mathbf{2 0 1 0}$ & $\mathbf{2 0 1 1}$ & $\mathbf{2 0 1 2}$ & $\mathbf{2 0 1 3}$ & $\mathbf{2 0 1 4}$ & $\mathbf{2 0 1 5}$ & $\mathbf{2 0 1 6}$ & $\mathbf{2 0 1 7}$ \\
\hline Slovenia & 14,1 & 13,6 & 4,2 & $-16,6$ & 10,2 & 6,9 & 0,6 & 3,0 & 5,7 & 5,0 & 6,4 & 10,5 \\
\hline Cyprus & 1,3 & 5,3 & $-0,6$ & $-4,1$ & 4,5 & 5,6 & $-2,7$ & 2,1 & 4,2 & 5,8 & 4,0 & 3,4 \\
\hline Malta & 17,5 & 10,9 & 19,4 & $-0,4$ & 6,9 & 1,4 & 7,0 & 0,9 & 3,2 & 3,5 & 4,5 & 4,3 \\
\hline Slovakia & 22,9 & 14,6 & 3,0 & $-16,8$ & 15,7 & 12,0 & 9,3 & 6,7 & 3,9 & 6,4 & 6,2 & 4,2 \\
\hline Estonia & 9,5 & 12,6 & 0,9 & $-20,3$ & 24,0 & 24,2 & 4,8 & 2,8 & 2,5 & $-0,7$ & 4,1 & 3,4 \\
\hline Latvia & 7,5 & 13,8 & 2,4 & $-12,9$ & 13,4 & 12,0 & 9,8 & 1,1 & 6,0 & 3,0 & 4,1 & 4,7 \\
\hline Lithuania & 12,6 & 3,2 & 13,5 & $-12,8$ & 18,9 & 15,4 & 12,4 & 9,9 & 3,3 & $-0,4$ & 3,5 & 13,1 \\
\hline
\end{tabular}

Source: [2]

In terms of export dynamics, the situation in particular countries, which later adopted the euro (Table 10) is different, but in no country hypothesis II was confirmed. In the examined countries there were fluctuations in export dynamics both before and after the adoption of the euro, with short downward or upward trends. However, in no country a persistently higher export growth has been noted after the adoption of the euro (excluding the crisis period in the financial markets).

\section{Changes in import dynamics}

The average import dynamics was higher for the majority of the examined period in the second group (countries of the euro zone with a stable economy) than in the third group (countries with a stable economy with national currencies. The only exceptions were the years 2006 and 2012, in which the average import dynamics was higher in Group III respectively by 3.2 percentage points and 0.5 percentage point. In 2009 , the decrease in import was lower in the second group by 0.7 percentage point than in the third group.

In Group I (PIIGS countries), the average growth rate of import was higher than in the third group in 2007 and 2014 - 2016. The sharp crisis and implemented sanative programs affected 
the level of import, which fell not only in 2009, as in all groups of countries, but also in 2008 and in 2011 - 2012. In Ireland, in which the nature of the crisis was different than in other PIIGS countries, in 2014 - 2016 there was high dynamics of import, respectively: 14.9\%, $26.0 \%, 16.4 \%$.

Table 11. Average import dynamics in particular groups of countries in $2006-2017$ (\%).

\begin{tabular}{|c|c|c|c|c|c|c|c|c|c|c|c|c|}
\hline Countries/Year & $\mathbf{2 0 0 6}$ & $\mathbf{2 0 0 7}$ & $\mathbf{2 0 0 8}$ & $\mathbf{2 0 0 9}$ & $\mathbf{2 0 1 0}$ & $\mathbf{2 0 1 1}$ & $\mathbf{2 0 1 2}$ & $\mathbf{2 0 1 3}$ & $\mathbf{2 0 1 4}$ & $\mathbf{2 0 1 5}$ & $\mathbf{2 0 1 6}$ & $\mathbf{2 0 1 7}$ \\
\hline Group I & 9,2 & 8,8 & $-1,7$ & $-12,6$ & 4,8 & $-2,6$ & $-5,5$ & 0,1 & 8,0 & 9,5 & 5,4 & 3,7 \\
\hline Group II & 7,7 & 6,2 & 3,9 & $-11,2$ & 10,2 & 5,9 & 1,5 & 1,8 & 5,0 & 5,2 & 4,5 & 4,5 \\
\hline Group III & 10,9 & 4,1 & 2,3 & $-11,9$ & 7,3 & 5,2 & 2,0 & 1,5 & 4,9 & 4,1 & 4,0 & 4,0 \\
\hline Group IV & 16,7 & 18,8 & 4,9 & $-16,1$ & 10,2 & 7,4 & 0,5 & 3,9 & 9,0 & 6,7 & 5,6 & 8,5 \\
\hline
\end{tabular}

Source: the authors' own calculations based on [2]

The highest average import dynamics from all groups of countries was recorded in Group IV, except in 2010 (the same level was also achieved by Group II), 2012 (higher level was recorded in Group II and Group III) and 2015 (higher level in Group I). In 2009, the deepest drop in import occurred in Group IV. As in the case of other indicators, a low base, the launch of development reserves as well as high import intensity of production, including export production had a crucial impact on the high average import dynamics.

In general, it can be stated that in the case of import the hypothesis I was confirmed.

Table 12. Imports dynamics in individual countries in $2006-2017$ (\%).

\begin{tabular}{|c|c|c|c|c|c|c|c|c|c|c|c|c|}
\hline Countries/Year & $\mathbf{2 0 0 6}$ & $\mathbf{2 0 0 7}$ & $\mathbf{2 0 0 8}$ & $\mathbf{2 0 0 9}$ & $\mathbf{2 0 1 0}$ & $\mathbf{2 0 1 1}$ & $\mathbf{2 0 1 2}$ & $\mathbf{2 0 1 3}$ & $\mathbf{2 0 1 4}$ & $\mathbf{2 0 1 5}$ & $\mathbf{2 0 1 6}$ & $\mathbf{2 0 1 7}$ \\
\hline Slovenia & 12,4 & 16,8 & 3,8 & $-18,8$ & 6,8 & 5,0 & $-3,7$ & 2,1 & 4,1 & 4,7 & 6,6 & 10,0 \\
\hline Cyprus & 5,7 & 10,5 & 12,5 & $-15,0$ & 8,0 & $-3,0$ & $-4,4$ & $-4,8$ & 4,6 & 7,4 & 6,8 & 10,1 \\
\hline Malta & 18,4 & 8,1 & 19,5 & 0,3 & 7,6 & $-0,5$ & 5,1 & 0,0 & $-0,2$ & 7,1 & 1,5 & $-0,9$ \\
\hline Slovakia & 19,5 & 9,4 & 3,6 & $-18,8$ & 14,7 & 9,6 & 2,5 & 5,6 & 4,8 & 8,4 & 3,7 & 3,8 \\
\hline Estonia & 20,7 & 13,0 & $-6,2$ & $-30,6$ & 21,2 & 27,2 & 9,7 & 2,0 & 3,6 & $-1,8$ & 5,3 & 3,8 \\
\hline Latvia & 21,4 & 17,4 & $-10,7$ & $-31,7$ & 12,4 & 22,0 & 5,4 & 0,4 & 1,2 & 2,1 & 4,5 & 9,4 \\
\hline Lithuania & 14,3 & 10,8 & 12,2 & $-28,0$ & 18,7 & 15,0 & 6,6 & 9,1 & 3,1 & 6,2 & 3,5 & 12,7 \\
\hline
\end{tabular}

Source: [2]

In the case of Slovenia and Latvia, since 2013 there has been an upward trend in import dynamics, however, it did not reach the level from before the adoption of the euro. In the case of Cyprus, after the adoption of the euro, there is relatively high import dynamics in the following two years :2008 and 2010, but in 2011-2013 its level is falling. Fluctuations in import dynamics occur in the Maltese, Slovakian, Estonian and Lithuanian economies. However, no country has a persistently higher import dynamics after the adoption of the euro (excluding the period of crisis in the financial markets), which means that hypothesis II has not been confirmed.

\section{Conclusions}

Hypothesis I was confirmed in the case of GDP dynamics only for the years 2006 - 2009 and for the entire examined period regarding the dynamics of export and import. The average dynamics of other indicators did not change according to the assumed 
hypothesis I. It was also stated that the euro did not prevent the PIIGS economies from returning to the path of growth after 2014.

The hypothesis II was confirmed only for Malta's average GDP dynamics. In the case of other countries and other indicators, the hypothesis II was not confirmed.

The hypothesis III has been confirmed in Group IV countries since 2014 and in the case of Slovenia, Cyprus, Estonia and partly Latvia (the downward trend in the dynamics of final consumption expenditure of general government broke down in 2017).

The obtained results do not allow for the complete falsification of the statement that using the common currency is a factor negatively affecting economic growth.

\section{References}

1. Eurostat, https://ec.europa.eu/eurostat/web/national-accounts/data/main-tables

2. OECD statistics, https://data.oecd.org/ 